\title{
Az intézeten kívüli szülés helyzetének és a szülésznők szerepének alakulása hazánkban
}

\author{
Vincze Felícia ${ }^{1}$ - Lipienné Krémer Ibolya ${ }^{2}$ \\ ${ }^{1}$ Szegedi Tudományegyetem, Általános Orvostudományi Kar, Klinikai Orvostudományi Doktori Iskola, Szeged \\ ${ }^{2}$ Semmelweis Egyetem, Egészségtudományi Kar, \\ Szülészeti és Nőgyógyászati Klinikai Ismeretek Tanszék, Budapest
}

\begin{abstract}
A XX. században a szülészeti ellátás intézményesítése nem jelentette az otthon szülések megszűnését, bár a tervezett intézeten kívüli szülések aránya minimálisra csökkent. A szerzők áttekintik a magyarországi bábák helyzetének átalakulását, az otthon szülés helyzetét. A magyar kormány 2011-ben törvényileg szabályozta a kórházon kívüli szülészeti ellátást, majd 2014. július 1 -jétől lehetővé tette a szülésznői várandósgondozást, ami előrelépést jelent a bábai modell kialakulása felé. A tanulmányban a szerzők bemutatják öt nyugati kutatás eredményeit, amelyek az otthon szülés biztonságosságának kérdésével foglalkoznak. Egy közelmúltban publikált tanulmányt is feldolgoznak, amelyben a kórházi beszállításokat több szempontból is elemezték. Végül megvizsgálják három magyar bábapraxis statisztikai adatait. Megállapítják, hogy az alacsony esetszámú hazai adatok ellenére a beszállítások aránya hasonló a külföldi tanulmányok adatsoraihoz. A kutatási eredmények és a gyakorlati tapasztalatok áttekintésével arra a következtetésre jutnak, hogy a résztvevők közötti tiszteletteljes kommunikáció és a családok felkészítése az esetleges kórházi transzportra lehet az alapja a zökkenőmentes ellátásnak. Orv. Hetil., 2016, 157(11), 415-423.
\end{abstract}

Kulcsszavak: otthon szülés, szülésznő, biztonság, kórház, beszállítás

\section{Changes in the situation in out-of-hospital birth and the role of midwives in Hungary}

The rate of homebirth decreased significantly by the 20th century, however, the practice has never disappeared. The Hungarian government issued a regulation of out-of-hospital birth in 2011 , then allowed midwives to provide prenatal care for low-risk mothers in 2014. These were great steps toward the midwifery model of care. In this study the authors gathered the statistics of three licensed Hungarian out-of-hospital service providers. Despite the low number of cases, the data confirm that the rate of hospital transports in Hungary is quite similar to those found in other countries. The authors present five different studies to demonstrate that home births are just as safe as hospital births. Finally, the authors summarize a study in which hospital transports based on several criteria were analyzed. The authors conclude that in these events, fear and prejudice influences the participants on either side, harming interprofessional relationships. To improve the care given, mutually respectful communication and education of families about the option of hospital transport are key issues.

Keywords: homebirth, midwife, safety, hospital, hospital transfer

Vincze, F., Lipien-Krémer, I. [Changes in the situation in out-of-hospital birth and the role of midwives in Hungary]. Orv. Hetil., 2016, 157(11), 415-423.

(Beérkezett: 2015. november 23.; elfogadva: 2016. január 26.)

\section{Rövidítések}

BSc = Bachelor of Science; kft. = korlátolt felelősségü társaság; NICE $=$ The National Institute for Health and Care Excellence; TÁMOP = Társadalmi Megújulás Operatív Program; $\mathrm{WHO}=$ World Health Organization
Magyarországon a szülések zöme intézményekben történik, a kórházon kívüli szülések száma ehhez képest elenyésző. Ennek ellenére szükséges és hasznos a szülészet e területével foglalkozni, mivel eredményeinek figyelmen 
kívül hagyása félreértésekhez vezethet, megnehezítheti az együttmúködést és a kölcsönös elfogadást. A szabályozás megjelenésétől függetlenül az otthon szülés kérdése mindig nagy érdeklődést váltott ki nemcsak a szülészeti szakmán belül, hanem az egész társadalomban. Míg Észak-Amerikában és Nyugat-Európában az intézetekben is múködik a szülésznői önállósság, addig hazánkban nem, így nálunk még inkább nehéz az otthon szülés elfogadása és beépülése a mindennapi gyakorlatba.

Jelen tanulmányban áttekintjük, hogyan változott a bábák, szülésznők szerepe a magyar társadalomban, hogyan jutottunk el az iskolázatlanságtól a fóiskolai diplomáig. Bemutatjuk azt az utat, amely az elsősorban intézeten kívüli munkától a szinte csak kórháziig vezetett, azt a folyamatot, ahogyan a szülések levezetése a bábák kezéből kikerülve a XX. század közepére orvosi feladattá vált, hogy a XXI. század fordulójára ismét felelősséget és önállóságot kapva megkönnyíthessék az orvosok munkáját. Áttekintünk öt külföldi tanulmányt, amelyeket számos helyen idéztek megjelenésük óta, és a felhasznált nagy esetszámok miatt eredményeik jelentősége vitathatatlan. Megmutatjuk, hogy a szabályozás milyen lehetőségeket hozott a magyar szülésznők életében, hogyan változott megítélésük, és milyen lépések állnak előttünk addig, amíg az intézeten kívüli szülés beépül a mindennapi gyakorlatba, elfogadott lesz és a benne dolgozók egyenrangúvá válnak a kórházakban és klinikákon dolgozó bábákkal. Feldolgozzuk három magyar bábapraxis statisztikáit, amelynek segítségével képet kapunk az intézeten kívüli szülés hazai helyzetéről.

\section{Bábák a magyar szülészet történetében}

A szülés körüli segítségnyújtás egészen a történelem előtti időkig nyúlik vissza. A bábák legfőbb feladata nem változott az idők során, ez pedig elsősorban nem más, mint segíteni a szüléseknél, azaz biztosítani a megfelelő körülményeket, és a kornak megfelelő tudással felügyelni a folyamat biztonságát. Feladatuk nemcsak a vajúdás és szülés támogatására korlátozódott, hanem már a várandósság és később a gyermekágyas időszak alatt nyújtott gondoskodást is magába foglalta [1]. Néprajzi kutatásokból tudjuk, hogy a bábák szerepe a paraszti társadalmakban különleges és fontos volt, amely átölelte az emberi életet a kezdetektől, a fogantatástól a halálig. Élet és halál munkájuknak - és ezáltal életüknek is - része volt, ezt önként vállalták, és vitték a terhét évtizedeken keresztül, sokszor saját egészségüket, szabadságukat, akár életüket kockára téve [1].

A középkorban Magyarországon, csakúgy, mint más országokban, a kórházaknak szülészeti szempontból nem volt jelentőségük, a szülések a családi otthonokban zajlottak, amelyeken férfiak, illetve orvosok csak nagyon ritkán vettek részt. A bábák akkor hívtak borbélysebészt, későbbi korokban orvost, ha olyan komplikáció merült fel, amit nem tudtak megoldani. Általában a nagyon gazdagok éltek ezzel a lehetőséggel, például uralkodócsalá- dok, nemesek - tehát az orvos részvételét a szülésen a kiváltságosak lehetőségének tekintették. Évszázadokkal később a polgárság, majd a legalacsonyabb néprétegek számára is elérhetővé vált az orvosi jelenlét [2].

Magyarországon bábaságról, mint szervezett képzéshez kötött, kritériumok alapján múködő foglalkozásról a XVIII. századig nem beszélhetünk. Nagyon kis létszámban múködtek okleveles bábák, akik külföldön tanultak és módosabb családokból származtak; többségben maradtak a cédulás bábák, akik csak gyakorlati oktatásban vettek részt megyei bábák mellett, illetve a paraszt bábák vagy egyszerü bábák, akik tapasztalatukból szerezték tudásukat, és minimális elméleti képzettséggel rendelkeztek [3]. A felvilágosodás kora nemcsak az orvosképzésben, hanem a szülésznők helyzetében is változást hozott. Mária Terézia uralkodása alatt a bábaügy rendezése is előtérbe került. Kötött esküformát alakítottak ki, kötelezték a bábákat cégtábla használatára, és oktatásuk is megkezdődött. Érdekességként az 1755-ös bábaszabályzatból idézünk: a bábák a tiszti főorvos hívására kötelesek előtte megjelenni, utasításait betartani, előttük vizsgát tenni, nehéz szülés esetén másik szülésznőt hívni. Orvos tudta és rendelése nélkül belső orvosságot nem adhattak, és tudatában kellett lenniük, hogy a szabályok megszegésének súlyos következményei lehetnek. Faji vagy vagyoni megkülönböztetés nélkül akár éjjel, akár nappal kötelesek voltak a bábák a vajúdót támogatni, szorgalommal és teljes körültekintéssel; józan és tisztességes életet kellett éljenek; „kerüljék a fecsegést és lelkiismeretük tiszta legyen, maguk között barátságban és egyetértésben éljenek" [2].

A bábák képzésének hiányossága és a borbélysebészek tudatlansága arra ösztönözte az orvostársadalom egyes tagjait, hogy tankönyv megírásával segítsék a helyzet megoldását. Magyar nyelven 1766-ban jelent meg először bábáknak írott tankönyv, Weszprémi István fordításában, „Bába mesterségre tanító Könyv” címen. A „Magyar bábamesterség” Szeli Károly által magyarra fordított változata 1777-ben látta meg a napvilágot. A terjedelme és részletessége miatt már szülészeti tankönyvnek tekinthető írás Steidele János bécsi orvos munkája. Ebben olvashatunk a reprodukciós szervek anatómiájáról, fiziológiás és patológiás szülések levezetésének módszereiről, a gyermekágyról, az újszülött ellátásáról és a bábák törvény előtti elszámolási kötelezettségéről is [1, 2, 4].

A törekvések ellenére évtizedekkel később is még mindig problémát okozott, hogy sok bába tanulatlanul, megfelelő képesítés nélkül dolgozott. A bábaügy XIX. század végi egyik legismertebb személyisége Tauffer Vilmos, szülész, egyetemi tanár, aki a bábaügy kormánybiztosaként gyors és eredményes megoldást szeretett volna a bábaképzés problémájára (1891), mivel a statisztikák katasztrofális helyzetet mutattak a csecsemőhalandóság és gyermekágyi betegségek területén. Tauffer célul tüzte ki, hogy minden faluban tanult bába múködjön, még akkor is, ha képzése minimális szintű. Ezért felállította a másodrendú bábaképzóket, ahol 6-8 hetes okta- 
tás keretein belül próbáltak szaktudást átadni a bábajelölteknek [1]. A XIX. század végén törvénybe iktatták a bábanapló vezetését, amelyben pontosabban nyomon követhetővé vált a bábák tevékenysége, például a szülési adatok vonatkozásában.

A szülések helyszínének fokozatos változása miatt a szülészeti ellátás egyre inkább orvosi feladattá vált, redukálva a szülésznők feladatkörét és egyben felelősségét is [2].

Érdekességként egy 1930-ban kiadott, „A szülészet tankönyve" címú munkából idézünk, amely orvosoknak íródott tankönyv és még a XX. században is említést tesz az intézeten kívüli szülésről, mint lehetséges alternatíváról: „Régebben rendesen »otthon « folyt le a szülés, a klinikai szülés félelmetes és a lehetőség szerint került kivétel volt. Ma más a helyzet. A klinikától való félelem lényegesen csökkent. Sok asszony szabadulni akar minden egyéni felelősségtől és meg van győződve arról, hogy a klinika biztosítja leginkább a szülés zavartalan lefolyását. E »modern « felfogással szemben épp oly kevéssé lehet kifogásunk, mint az »ódivatú « ragaszkodással szemben, hogy a normális szülés magánházban folyjon le. Annak az asszonynak, aki szeretettel, szakszerúen és körültekintéssel beszerez és előkészít mindent, ami a szüléshez szükséges, és aki nem lakik oly szưkösen, hogy nehéz óráiban ne találna házában nyugodalmas helyet, másrészt nem lakik oly távol, hogy emiatt esetleg segítség nélkül maradna, annak nincs szüksége klinikára, ha rendelkezésre áll egy derék orvos és egy jó bába. Tudatosan túloz, aki az ellenkezőjét állítja" [5].

A szülészet egységes tanításának igénye jelen volt az 1900-as évek elején is, azonban az első világháború viszszavetette ezeket a próbálkozásokat. A háború után lassan újra előtérbe került a szülészeti ellátás korszerüsítése, az anya- és csecsemővédelem. A következő évtizedekben a képzés minősége, színvonala és hossza is változott, annak megfelelően, ahogyan a rendelkezésre álló ismeretanyag is bővült [2]. A 20-as évek elején a bábaképzés ideje 10 hónapra emelkedett, majd ez kiegészült még 2 hónap gyakorlati képzéssel [3].

Az 1960-as évek után a szülések kórházakban és szülőotthonokban történtek, amivel a falu bábája és ezzel együtt a népi szokásvilág által szabályozott bábaság is eltünt [1].

A szülésznók képzési ideje 1947 és 1976 között kettő évre változott. Ennek oka, hogy a képzés a 3640/1949. számú kormányrendelet értelmében beolvadt az egészségügyi szakiskolák egységes rendszerébe. Így 1965-től csak azok választhatták e szakirányt, akik érettségivel rendelkeztek. A képzés keretein belül 1973-ban megjelenik a perinatalis ellátás, gondozás fontossága [6]. A nappali tagozaton 1994-ben elkezdődött a hároméves képzés [7]. 2000-től indult egy átmeneti időszak, amely lehetővé tette, hogy a korábban másféle képzési formában részesültek különbözeti vizsgát tegyenek. A program neve „Szülésznői Híd”. Így a szakképesítést szerzett szülésznők végzettségeit felsőfokúnak fogadták el. Ez- után megindult az érettségire épülő hároméves képzés $[3,6]$. Igazi változást a 2006-os év hozott, amikor elindult a négyéves, diplomát adó BSc (Bachelor of Science) képzés nappali és levelező formában. A képzés során alkalmassá teszik a hallgatókat alacsony kockázatú várandósok önálló gondozására és szülések önálló kísérésére. A jelenleg is hatályban lévő, az Európai Parlament és a Tanács 2005/36/EK irányelve szerint a szülésznők képzésük során alkalmassá válnak „spontán szülés levezetésére, beleértve szükség szerint a gátmetszést igénylő eseteket, sürgős esetben pedig a farfekvéses szüléseket". Továbbá egy 2013-ban az Európai Unió és a Magyar Állam által támogatott TÁMOP 6.2.2/B/09 projekt keretében a Magyar Egészségügyi Szakdolgozói Kamara kivitelezésében elkészült az egészségügyi szakdolgozói terület hatásköri listája, amely szerint a szülésznő rendelkezik az alábbi készségekkel és/vagy képességekkel (részlet): „A szülés haladásának nyomon követése, Kontrakciók megfigyelése, értékelése, Az elől fekvő rész helyzetének nyomon követése, Episiotomiát végez, amenynyiben szükséges, Élettani szülést vezet..., Ellátja a gátmetszést/gátrepedés sérüléseit, amennyiben szükséges..." A fentiek értelmében a Magyarországon végzett szülésznók gyakorlati és elméleti tudása révén alkalmasak alacsony kockázatú várandós gondozására, szülésének önálló kísérésére és az anya és újszülött szülés utáni ellátására. Az önálló szülésznői munkát a jelenleg érvényben lévő, várandósgondozást és intézeten kívüli szülészeti ellátást szabályozó kormányrendeletek is ehhez a végzettséghez kötik, amiből láthatjuk, hogy milyen hosszú utat kellett megtenni ahhoz, hogy a képzetlen, de jó szándékú bábáktól eljussunk oda, hogy mind a szülésznői képzés, mind a törvényi keretek lehetővé tegyék, hogy a szülőpárokat bármely általuk választott helyszínen alapos és modern szaktudással, felsőfokú végzettséggel rendelkező bábák támogathassák.

\section{Szakirodalmi áttekintés}

Intézeten kívüli szülés esetén is az anya és a magzat biztonságának megteremtése a legfontosabb feladat. Számos tanulmány és a fejlett nyugati országok gyakorlata is bizonyítja, hogy alacsony kockázatú várandósok esetén, jól képzett szakszemélyzettel és folyamatos kockázatbecsléssel, az intézeten kívüli szülések ugyanolyan biztonságosak, mint a kórháziak. Az alábbi öt kutatás elemzése is ezt a tényt támasztja alá.

Köztudott, hogy Hollandiában igen magas az otthon szülések aránya. 45 évvel ezelőtt még minden alacsony kockázati csoportba tartozó várandós otthon szült, azaz a szülések kétharmada intézményen kívül történt, 1965ben ez az arány 69\% volt. Az 1970-es évektől választhatják az anyák a szülésznő által önállóan kísért kórházi szülést is, részben ennek eredményeként az otthon szülések száma 1991-re 31\%-ra csökkent. A szülésznők által kísért szülések fele ma már kórházakban történik, ahonnan szülés után néhány órával az anyát és az újszülöttet haza- 
bocsáthatják. Ennek a változásnak több lehetséges okát is felsorolják a szerzők, amelyek közül kettőt említünk meg: az intézeti post partum ellátás idejének csökkentése, illetve az intézeti önálló szülésznői munka megteremtése [8]. Wiegers és mtsai kutatásának eredményei a holland szülészeti viszonyokról 1996-ban jelent meg [9]. 97 szülésznő összesen 1836 esetét vizsgálták, akik alacsony kockázati csoportba tartoztak és tervezetten szültek kórházban vagy otthon orvos nélkül. Számos perinatalis mutatót elemeztek, köztük a magzati distresszt, eszközös szülésbefejezést, anyai és magzati sérüléseket. Eszerint a primiparák csoportjában nem mutatható ki jelentős különbség kórházi és otthon szülések esetében, míg multiparák között otthon szülés esetén ezek a mutatószámok jobbak voltak, mint kórházban történt szüléseknél.

Kenneth C. Johnson kanadai epidemiológus 2005-ben megjelent tanulmányának eredményei is alátámasztják, hogy szakképzett szülésznők által kórházon kívül vezetett szülések ugyanolyan biztonságosak, mint a kórházi szülések [10]. Az 5418 szülésből 655 anyát kellett kórházba szállítani megindult vajúdással (12,09\%). A beszállítások $83,4 \%$-a vajúdás során történt, elsősorban a szülés valamely szakaszának elhúzódása, fájdalomcsillapítás vagy anyai kimerültség miatt. A szülés utáni intézetbe szállítások okai között az anyai fokozott vérzés, placentaretenció és az újszülött légzési nehézségei szerepeltek. Az alacsony kockázati csoportba tartozó tervezett kórházi és otthon szüléseket összehasonlítva, a beavatkozások aránya a következőképpen alakult: folyamatos magzati monitorizálás: $84,3 \%-9,6 \%$, gátmetszés 33,0\%-2,1\%, császármetszés 19,0\%-3,7\%, vákuumos szülésbefejezés 5,5\%-0,6\%. Az 5418 eset adatfeldolgozásának eredménye megegyezik a szerzők által összehasonlított más észak-amerikai tanulmányok adataival, miszerint az intra partum és neonatalis mortalitás intézeten kívül és intézeti szülés esetében is hasonló, 1,7 per 1000 szülés volt.

Egy 2009-ben közzétett holland kutatás összehasonlította a képzett szülésznők által vezetett tervezett kórházi és otthon szüléseket a perinatalis kimenetel szempontjából [11]. De Jonge és mtsai kohorsztanulmányukban 2000 és 2006 között hazájukban, Hollandiában történt alacsony kockázatú eseteket dolgoztak fel. A szülés megindulásakor az 529688 kismama 60,7\%-a szeretett volna intézeten kívül szülni, 30,8\% kórházban, és 8,5\%-uknál a helyszín előzetes eltervezése nem ismert vagy a dokumentációkból nem megállapítható. Az otthon szülést választók között nagyobb arányban voltak 25 évnél idősebbek, holland származásúak, multiparák és a közép- és felső osztályba tartozók. A kutatók a perinatalis morbiditási és mortalitási eredményeket hasonlították össze a két tervezett helyszín között. Az adataikból kiolvasható, hogy alacsony kockázati csoportba tartozók esetén kórházi szülésekhez viszonyítva a perinatalis mortalitásnak és az újszülött intenzív ellátás alá kerülésének nincs nagyobb esélye intézeten kívüli szülés esetén sem. Habár egyes tényezőket, mint a 35 év feletti kort vagy a pri- miparitást magasabb számú kedvezőtlen kimenetellel lehet összefüggésbe hozni, ezek azonban a szülés választott helyszínével nem voltak összefüggésben.

A British Medical Journal 2011-ben jelentette meg a Birthplace in England Collaborative Group kutatását, amely 64538 alacsony kockázati csoportba tartozó várandós szülésének eredményeit hasonlította össze különböző szülési helyszíneken: a család otthona, születésközpont, kórházhoz csatolt születésközpont, kórház [12]. Habár a National Institute for Health and Clinical Excellence (NICE) által kiadott irányelvekben addig is hangsúlyozták, hogy a kórházon kívüli szülés nagyobb eséllyel végződik hüvelyi úton és a beavatkozások aránya alacsonyabb, mint az intézményi szülések esetén, de az Angliában elérhető összes szülési helyszínre vonatkozóan nem voltak megfelelő kutatási eredmények a perinatalis mutatókat illetően. (Angliában az összes szülés körülbelül 8\%-a történik olyan helyen, ahol nincs jelen szülész szakorvos.) A szülésznői gondozást választók között nagyobb arányban szerepeltek a fehér és idősebb korosztálybeliek, illetve olyan nők, akik folyékonyan beszéltek angolul és a módosabb középosztályhoz tartoztak. A kórházba szállítási arány mindhárom, intézeten kívüli helyszín esetén számottevően magasabb volt nulliparák esetén $(36 \%-45 \%)$, mint multiparák esetén (9\%-13\%). A vizsgált mutatók a perinatalis mortalitás és az intra partum eseményekkel összefüggő morbiditás: magzati elhalás a szülés megindulása után, korai újszülött-elhalálozás, encephalopathia, meconiumaspirációs szindróma, brachialis plexussérülés, törött humerus vagy kulcscsont. Az összes vizsgált szülésből 250 esetben történt negatív kimenetel, azaz 4,3 ilyen esemény volt 1000 szülésre vetítve (95\% CI 3,3-5,5). Az eredmények alapján nulliparák esetén a perinatalis morbiditás vagy mortalitás aránya magasabban alakult otthon szülés esetén, mint a másik három vizsgált helyszínen (adjusted odds ratio 1,75), multiparák esetén azonban nem mutatkozott szignifikáns különbség a négy helyszín között. „Normálszülés”, azaz olyan szülés, ahol nem történt szülésindukció, nem használtak epiduralis vagy spinalis érzéstelenítést, nem hajtottak végre gátmetszést és nem fogóval vagy vákuummal fejeződött be a szülés, $58 \%$-ban történt szülészeti osztályon, 76\%-ban kórházhoz csatolt születésközpontban, 83\%-ban születésközpontban és 88\%-ban otthon szülésnél. Az eredmények alapján a szerzők azt a következtetést vonták le, hogy alacsony kockázatú várandósság esetén nulliparáknak és multiparáknak egyaránt felajánlható bármelyik szülési helyszín.

Cheyney és mtsai tanulmánya 2014-ben jelent meg [13], amelyben 16924 tervezett, intézeten kívüli szülés kimenetelét vizsgálták. A 16924 szülés 89,1\%-a fejeződött be kórházon kívül, az intra partum beszállítás aránya 10,9\% volt. A beszállítások 40,7\%-a elakadt vajúdás miatt történt. Egyéb okok közt szerepel a magzati distressz vagy meconiumos magzatvíz, az anya kimerültsége vagy igénye fájdalomcsillapításra, illetve fekvési vagy tartási rendellenesség. A tanulmány kiemeli, hogy null- 
iparákat háromszor annyi esetben kellett beszállítani, mint multiparákat. A sikeres szülést követő órákban az anyák 1,5\%-át szállították intézménybe elsősorban fokozott vérzés vagy visszamaradt placenta miatt. Az újszülöttek 0,9\%-a került kórházba légzési nehézség vagy 7 alatti Apgar-érték miatt. Az intra partum magzati mortalitás 1,30 per 1000 szülés, a korai újszülötthalálozás (születés után egy héten belül) 0,41 per 1000, a késői pedig 0,36 per 1000 szülés. A közel 17000 várandós 94\%-a szült meg hüvelyi úton (ezen belül 5\%-nál kevesebb esetben volt szükség oxytocinos szülésgyorsításra vagy epiduralis fájdalomcsillapításra a kórházi beszállítás után). Az itt bemutatott alacsony kockázati csoportba tartozó kismamák 6\%-os császármetszési aránya alátámasztja a WHO javaslatát, amely ilyen esetekben 10\%nál magasabb császármetszési arányt nem ajánl [14].

\section{Otthon szülésből kórházba: a résztvevők hozzáállása és egymásra gyakorolt hatásuk}

A fenti tanulmányokból is látható, hogy megkezdett otthon szülésből az anyák mintegy 10\%-a kerül kórházba a vajúdás során vagy a közvetlen post partum időszakban kialakult komplikációk miatt [15]. A beszállítások legtöbbje nem vészhelyzeti eset, legnagyobb részben a szülés valamelyik fázisának elhúzódása miatt válik szükségessé. Ilyenkor általában oxytocinos fájáserősítést alkalmaznak, ami csak intézeti körülmények között indítható. A Magyarországon múködő praxisok körében a kórházi beszállítások a külföldiekhez hasonló arányban történtek és történnek.

Egy ilyen esemény legtöbb esetben feszültséget jelent mind a szülők és szülésznők, mind a kórházi személyzet számára. Cheyney és munkatársainak 2014-ben végzett kutatása szerint a kórházi személyzet gyakran kényelmetlennek érezheti, ha otthon szülésból beszállított esettel kell foglalkoznia [15]. Egyrészt valószínúsíthetően többségük nem ért egyet a kórházon kívüli szülés lehetőségével, azt veszélyesnek tartja és felelőtlennek azokat, akik ezt választják vagy ebben segédkeznek. Másrészt át kell venniük egy számukra ismeretlen esetet, egy másik ellátó páciensét kell kezelniük, a fellépett komplikációt megoldaniuk. A szerzők feltételezik, hogy a háttérben az említett okokon kívül a perektől való félelem is meghúzódhat. Harmadrészt nem rendelkeznek elegendő rutinnal a kórházon kívüli egészségügyi dolgozóval való kommunikációban, fóleg ilyen kiemelten stresszes helyzetekben.

Cheyney és mtsai [15] otthon szülésról szóló cikkükben a kórházi beszállításokat számos érdekes szempontból elemzik, többek között a demográfiai mutatók, a praenatalis rizikófaktorok, a szülés módja (hüvelyi vagy asszisztált), illetve a gesztációs idő szempontjából is. Felhívják a figyelmet arra a jelenségre, hogy a kórházi személyzet csak a beszállításokkal végződő eseteket látja, fóleg ezekre emlékszik, azok közül is elsősorban azokra, amelyek különösen nehezek voltak. Azt általában nem tudják, hogy hányan szülnek meg kórházon kívül sikere- sen, mindenféle komplikáció nélkül. Ha errôl esetleg szó esik, akkor sem elismerés a válasz, hanem inkább a szerencsének tulajdonítják a pozitív kimenetelt, kevésbé a szülés természetes folyamatának vagy a szülésznők szaktudásának. Így az ő szemszögükből nézve minden otthon szülés kórházi beszállításnak tünik, mert csak ezt látják, tulajdonképpen a kórházon kívül dolgozókat és az otthon szüléseket csak a kivételek és nem a tényleges eredményeik alapján ítélik meg.

Cheyney kutatása szerint [15] ugyanakkor ehhez azt is hozzá kell tenni, hogy az otthon szülést választók között esetenként olyanok is vannak, akik minden orvosi beavatkozást és segítséget elutasítanak, minden körülmények között kerülendőnek, feleslegesnek és veszélyesnek tartva a kórházi ellátást. Ezeknek az eseteknek a kezelése nagyon nehéz mind a kórházi személyzetnek, mind a beszállító szülésznőknek, és gyakran negatívan befolyásolják a beszállító szülésznők és a család kapcsolatát is.

Ezek mellett az antropológus kutatók eredményei azt is mutatják [15], hogy a kórházi beszállításoknál minden résztvevőben megjelenhet a félelem. A tanulmány szerint a bábák félnek az esetleges megalázó bánásmódtól, félnek, hogy a kismamájukkal hogyan fognak bánni, mi fog velük történni. A kórházi dolgozók félnek a beszállított esettől, ami ennek ténye miatt eleve valamiféle komplikációt jelent, félnek, hogy ha valami nem jól végződik, őket vonják felelősségre. Az anya és az apa pedig félnek a megjegyzésektől, hibáztatástól, diszkriminációtól. Mindezen félelmeknek következtében a beszállító szülésznők, kórházi orvosok és szülésznők közötti kapcsolat nagymértékben sérülhet, a beszállítások érzelmi szintű kezelése ritkán közelíti meg az ideális állapotot.

Cheyney említett tanulmánya hangsúlyozza továbbá azt is [15], hogy a tiszteletteljes kommunikáció kevésbé a bába személyes érzései miatt fontos, mint inkább a kismama miatt. Az anyuka tervezett otthon szülésből bekerül a kórházba, idegen környezetbe, idegenek közé, nem tudja, milyen beavatkozások előtt áll, protokollok milyen sorozata vár rá. Természetes, hogy a bábától kér tanácsot, ha döntenie kell, mivel köztük alakult ki bizalmi kapcsolat, tőle várja a megerősítést. Minden olyan szó vagy gesztus, ami a szülésznőt/bábát kritizálja, egyben a szülők kritikája is, foóként azért, hogy megpróbálták az intézeten kívüli szülést. Ez pedig azt eredményezheti, hogy akármilyen támogató is a kórházi személyzet az anyával szemben, ha kritikus a szülésznővel, elidegeníti az anyát. Ugyanez igaz fordítva is, ha a személyzet tisztelettel irányul a bába felé, az anya azt fogja érezni, hogy döntését a szülés helyszínét és szülészeti ellátót illetően tiszteletben tartják. A bába képességeinek vagy transzport előtti ellátásának kritikája, az ellenszenv explicit vagy implicit kifejezése, különösen a kismama vagy apa jelenlétében, rendkívül negatív hosszú és rövid távú hatása miatt kerülendő.

Cheyney és mtsai eredményei szerint [15] a kórházi ellátók általában feltételezik, hogy aki otthon akart szülni, biztosan elutasít minden beavatkozást. Az otthon szülést 
választók valóban gyakran tesznek fel kérdéseket és szeretnék tudni, hogy mi miért történik, milyen következményei lesznek vagy lehetnek egy-egy beavatkozásnak, de a kutatás eredményei szerint ezt azért teszik, mert elég tudatosak és motiváltak, így részt szeretnének venni az őket érintő döntésekben, legalább a korrekt és részletes tájékoztatás szintjén.

\section{Az otthon szülés helyzetének és szabályozásának alakulása hazánkban}

A tervezett kórházon kívüli szülések aránya Magyarországon a XX. századra minimálisra csökkent. Megjelentek azonban a szülőotthonok, amelyek átmenetet képeztek a kórházi és otthon szülések között, és elsősorban a vidéken, falvakban élő családokat látták el. 2005-ben megszűnt az utolsó szülőotthon is, ezzel hivatalosan minden szülést egészségügyi intézményhez rendeltek.

A szülészeti ellátás intézményesítése azonban nem jelentette a kórházon kívüli ellátás teljes megszúnését. Otthon szülések továbbra is történtek, viszont a jogilag rendezetlen körülmények az ellátást nyújtók és a családok számára is kockázatokkal és kellemetlen következményekkel járhattak. A magyar kormány a kialakult helyzet kezelésére 2011-ben léptette hatályba a 35/2011. (III. 21.) Korm. rendeletet (az Egészségügyi Közlönyben megjelent rendelet internetes elérhetősége: http:// www.kozlonyok.hu/kozlonyok/Kozlonyok/6/ PDF/2011/8.pdf), amely az intézeten kívüli szülészeti ellátás szabályozását tűzte ki célul. A kormányrendeletet létrehozása óta 2012 januárjában módosították, ezzel a gyakorlatban is lehetôvé tették az engedélyek megszerzését, mivel megszünt az a zsákutcás helyzet, ami az engedély megszerzéséhez kórházi gyakorlatot írt elő azoknak az ellátóknak, akik alapvetően intézeten kívüli szüléseknél segédkeztek.

A minisztérium és a szakma a rendelet megalkotásával arra törekedett, hogy a kórházon kívüli szüléseket biztonságossá, rendezetté és központilag szabályozottá tegye. Ennek érdekében a rendelet részletesen meghatározza a személyi, tárgyi és higiénés feltételeket, illetve az intézeten kívüli szülés kizáró okait és az intézetbe szállítás indikációit. Minden szülésen két szakember vesz részt, aki szülész-nőgyógyász szakorvos vagy felsőfokú végzettséggel rendelkező szülésznő lehet. Az intézeten kívüli szülést választók is részt vesznek a hivatalos, állami várandósgondozásban, aminek következtében a kockázatbecslés folyamatos. Az alacsony kockázatú kismamák várandósságának gondozását 2014. július 1-jétől szülésznő is végezheti önállóan, ami egyrészt terhet vehet le a túlterhelt szülész szakorvosok válláról, másrészt lehetőséget ad arra, hogy a kismamák, családok a szülés előtt több alkalommal is találkozhassanak a szülésznőkkel, ami a biztonságérzetet nagyban meghatározó bizalmi kapcsolat kiépítéséhez elengedhetetlen. (A várandósgondozást szabályozó 26/2014. (IV. 8.) EMMI rendelet internetes elérhetősége: http://www.kozlonyok.hu/
nkonline/MKPDF/hiteles/mk14052.pdf) Az intézeten kívüli szülést választók esetében azért nagy elörelépés a szülésznői várandósgondozás megvalósulása, mert az utat nyitott az úgynevezett bábai modell hazai kialakulása felé, ami a fejlett országokban már évtizedek óta jól múködik. A bábai modellnek fontos része a kismama várandósság alatti gondozása is, amely alapját képezi a bizalmi kapcsolat kialakulásának, mire a vajúdás és szülés ideje elérkezik. Ehhez nyújt törvényes keretet a várandósgondozási rendelet.

Az intézeten kívüli ellátást nyújtó felelős és helyettes felelős személyek feladata, hogy a várandós anyát a szülésre és gyermekágyas időszakra felkészítsék, a várandósság alatti rutinvizsgálatokat elvégezzék; a labor-, ultrahang- és egyéb vizsgálatok eredményeit figyelemmel kövessék és szükség esetén további vizsgálatokat kérjenek. Amennyiben olyan állapot alakul ki, ami kizárja az anyát a szülésznői várandósgondozás vagy az intézeten kívüli szülés lehetőségéből, akkor feladatuk ezt az anyával közölni és intézkedni az ellátás szakorvosnak történő átadásáról.

Az intézeten kívüli szülészeti ellátást szabályozó rendelet értelmében a vajúdás alatt és a szülés után az ellátóknak teljes körü figyelemmel kell eljárniuk az anya és magzat, majd az újszülött állapotának gondos felmérésével. Ezt szolgálja a két szakember folyamatos jelenléte és a protokolloknak megfelelő anyai és magzati állapotmonitorizálás. Amennyiben olyan rendellenességet vesznek észre, ami miatt az intézeten kívüli ellátás már nem biztonságos, a háttérkórházba kell szállítaniuk vagy szállíttatniuk az anyát és/vagy az újszülöttet.

Az intézeten kívül múködő szülészeti ellátóknak is kiemelt feladata, hogy a komplikációkat kellő időben felismerjék és kezeljék. Ennek érdekében kötelező újraélesztő tanfolyamok elvégzése, másrészt a szaktudás frissen tartása önképzéssel, illetve szervezett tanfolyamokon keresztül. Emellett sürgető szükség lenne az intézeten kívül dolgozó szülésznók munkájára vonatkozó szakmai irányelv megjelenésére, amely nem csak minőségbiztosítást jelenthetne, hanem a legújabb evidenciák ismerete és alkalmazása az ellátás biztonságát is növelhetné.

\section{Hazai bábapraxisok statisztikai adatai}

Magyarországon négy bábapraxis múködik a kormányrendelet életbe lépése óta. Az első hazai szolgáltató 2012. március 12-én kapta meg múködési engedélyét (A Te Szülésed Kft.) hódmezővásárhelyi székhellyel, a másik három praxis budapesti székhelyű. Az Életfa Bábapraxis elsôsorban Budapest és Pest megye területén múködik, a Bábakalács Kft. és Születésház Kft. az ország egész területén vállal szüléseket.

Az 1. táblázatban három praxis szüléseinek és beszállításainak, illetve a császármetszések számát közöljük, amelyeket a szolgáltatók ügyvezetői bocsátottak rendelkezésünkre. A Születésház Kft. nem szolgáltatott adatokat a statisztikáiról. Az intézeten kívüli szülészeti ellátás 
Magyar bábapraxisok eseteinek, sikeres szüléseinek, beszállításainak és a beszállított esetek császármetszéseinek száma. Saját szerkesztés 2015-ös magyar adatközlések felhasználásával

\begin{tabular}{lllll}
\hline & $\begin{array}{l}\text { A Te } \\
\text { Szülésed } \\
\text { Kft. }\end{array}$ & $\begin{array}{l}\text { Életfa } \\
\text { Bábapraxis } \\
\text { Kft. }\end{array}$ & $\begin{array}{l}\text { Bábakalács } \\
\text { Kft. }\end{array}$ & Összesen \\
\hline Esetszám (fó) & 139 & 160 & 143 & 442 \\
$\begin{array}{l}\text { Sikeres intézeten } \\
\text { kívül kísért szülés } \\
\text { (fó) }\end{array}$ & 120 & 135 & 128 & 383 \\
$\begin{array}{l}\text { Beszállítás (fó) } \\
\text { Császármetszés (fó) }\end{array}$ & 11 & 3 & 15 & 59 \\
\hline
\end{tabular}

is az anya, a magzat, majd az újszülött biztonságát tartja szem előtt. Ezt szolgálják a várható vagy fellépő komplikációk esetén történő beszállítások is, így ezek az adatok nem a szolgáltatók kudarcaként, hanem a biztonságra való törekvés felelős döntéseként értelmezhetőek.

A Te Szülésed - Intézeten Kivüli Szülészeti Ellátást Nyújtó Kft. 2012-ben 23, kórházon kívüli szülés során nyújtott ellátást, amelyból 5 fejeződött be intézetben $(21,7 \%)$. Az 5 esetból egyszer történt sürgósségi beszállítás mentővel kedvezőtlen magzati szívhang miatt. A beszállított esetekből 3 alkalommal császármetszéssel végződött a szülés (13\% a teljes mintára vetítve). 2013ban 29 szülésnél nyújtott ellátást, amiből 3 fejeződött be kórházban (10,3\%), mindhárom császármetszéssel. 2014-ben 42, intézeten kívül megkezdett szülésből 6 fejeződött be kórházban (14\%), három császármetszéssel (7\%). A szülés megindulása előtti időszakban kialakult kizáró okok között több esetben szerepelt a magzat farfekvése, kettő esetben koraszülés történt és egy esetben túlhordás.

Az Életfa Bábapraxis 160 esetében a megkezdett otthon szülésből 135 asszony, azaz 84\%-uk szült sikeresen intézeten kívül, 16\%-uk került kórházba. Az ante partum időszakban több kismama elesett az intézeten kívüli szülés lehetőségétől, az alábbi okokból: koraszülés, idő előtti burokrepedés meconiumos magzatvízzel, toxaemia, nagy magzat, magzati retardáció gyanúja, fejlődési rendellenesség gyanúja, illetve betöltött 42 . hét.

A Bábakalács Kft.-vel 2013-ban 82 anya tervezte az intézeten kívüli szülést, majd 75, otthon megindult szüléséből 9 kórházban (12\%), ebből 2 (2,6\%) császármetszéssel fejeződött be. Az egyik beszállítás fájásgyengeség miatt történt, a másik esetben a kismama kérte a kórházba szállítást. Ennél a praxisnál 2014-ben szintén 82 anya jelentkezett, 68 szülés ellátását kezdték meg otthon, közülük 6 került intézetbe $(8,8 \%)$ : 5 asszony fájásgyengeség miatt és 1 toxaemia gyanúja miatt. A 6 beszállításból a toxaemiás eset fejeződött be császármetszéssel (1,5\%). A szülés megindulása előtt a következő okok szerepelnek a kiesés okai között: idő előtti burokrepedés meconiumos magzatvízzel, farfekvés, magzati distressz, nőgyógyászati betegség, koraszülés, túlhordás, illetve 12-en döntöttek úgy a várandósságuk alatt, hogy mégsem kórházon kívül szülnek.

Mindhárom szolgáltató beszállított eseteinél a császármetszés indikációja forgási vagy tartási rendellenesség, téraránytalanság vagy magzati distressz volt.

Minthogy alig néhány éve van lehetőség Magyarországon legálisan kórházon kívüli szülészeti ellátást nyújtani, így a múködő szolgáltatók adatai, a minták alacsony elemszáma miatt, statisztikailag messzemenő következtetések levonására nem nyújtanak lehetőséget, de az irányvonalakat jól mutatják.

A magyar szolgáltatók százalékos arányszámait a 2 . táblázat mutatja, két többezres esetszámot feldolgozó nyugati tanulmány eredményei mellett. Ez utóbbi publikációk elemzésére a cikk korábbi fejezetében került sor. $\mathrm{Az}$ 1. és 2. táblázatból kiolvasható, hogy a magyar szolgáltatók által kísért szülések döntő többsége intézeten kívül, komplikáció nélkül, sikeresen zajlott le. Megfigyelhető, hogy az Életfa Bábapraxis és a Bábakalács Kft. esetében a császármetszések aránya a nemzetközi átlagnál is alacsonyabb, $A$ Te Szülésed Kft.é viszont annál magasabb. A háttérben meghúzódó okokat keresve felmerülhet többek között az a kérdés is, hogy összefügghet-e a választható háttérkórházak száma, beállítódása (például alternatív szülészet elfogadottsága, alacsonyabb beavatkozási arány) a beszállított szülések folytatódásával, a császármetszéssel befejezett szülések arányával, azaz ezek aránya összefügghet-e azzal, hogy fóvárosi vagy vidéki helyszínen zajlik a szülés. A magyar bábapraxisok statisztikái a külföldi kutatásokhoz viszonyított alacsony elemszám ellenére azokhoz hasonló arányokat mutatnak. Ez alapján remélhetjük, hogy az intézeten kívüli szülészeti ellátás biztonságossága a következő években, évtizedekben a külföldi irányvonalakhoz hasonlóan alakul.

2. táblázat | A beszállítások és császármetszések aránya az intézeten kívüli szülések körében. Saját szerkesztés, Cheyney 2014, Johnson 2005 és magyar adatközlé sek felhasználásával

\begin{tabular}{|c|c|c|c|c|c|c|}
\hline & $\begin{array}{l}\text { Cheyney és } \\
\text { mtsai (2014) }\end{array}$ & $\begin{array}{l}\text { Johnson és } \\
\text { Daviss (2005) }\end{array}$ & A Te Szülésed & $\begin{array}{l}\text { Életfa } \\
\text { Bábapraxis }\end{array}$ & Bábakalács & $\begin{array}{l}\text { Magyar praxisok } \\
\text { összesítve: }\end{array}$ \\
\hline Sikeres, intézeten kívüli szülés (\%) & 89,10 & 87,91 & 86,33 & 84,37 & 89,51 & 86,65 \\
\hline Beszállítás (\%) & 10,90 & 12,09 & 13,67 & 15,63 & 10,49 & 13,35 \\
\hline Császármetszés (\%) & 5,20 & 3,69 & 7,91 & 1,88 & 2,10 & 3,85 \\
\hline Császármetszés/beszállítás (\%) & 47,70 & 30,53 & 57,89 & 12,00 & 20,00 & 28,81 \\
\hline
\end{tabular}




\section{Következtetések}

A dolgozatunkban bemutatott tanulmányok ÉszakAmerikában és Nyugat-Európában készültek, ahol a szülésznők igen sokféle képzettséggel bírnak, kezdve a formális oktatásban nem részesült bábáktól a mesterfokozattal rendelkezőkig. Hazánkban a szülésznők, hasonlóan más egészségügyi szakdolgozókhoz, alárendeltek a magasabb végzettségű és tudású orvosoknak. Intézményi keretek között a szülésznőknek nincs önálló döntéshozatali joguk, és a legtöbb intézményben az orvos a szülésznő véleményének meghallgatása nélkül dönt egyegy eset kapcsán. Így a jelen körülmények között nem ritkaság, hogy a kórházon kívül dolgozó, önállóan müködő szülésznőket, szaktudásukat, véleményüket, észrevételüket nem, vagy csak fenntartással fogadják esetleges konzultáció vagy beszállítási szituáció kapcsán.

Habár képzettségük alapján a magyar szülésznők is alkalmasak az alacsony kockázatú szülések önálló ellátására, jelenleg hazánkban egy kórház kivételével erre egyelőre nincs lehetőség. Ezzel szemben számos fejlett nyugat-európai és észak-amerikai országban az alacsony kockázatú kismamákat szülésznő gondozza és önállóan kíséri a szülésüket, lásd: bábai modell. Szakorvossal abban az esetben konzultálnak vagy hívják be a szüléshez, ha probléma merül fel.

Külföldi mintára hazánkban is kialakulhatna egy olyan rendszer, amelyben az alacsony kockázatú esetek ellátása során a bába/szülésznő egyenrangú szerepet kaphat az orvosokkal, mivel ezekben az esetekben szaktudása és gyakorlata elegendő lehet a felelős döntéshozatalhoz. Ez a felfogás egyelőre teljesen idegen a magyar orvostársadalomtól és talán a szülésznők többségétől is. A gyakorlattal azonban egyre nagyobb önbizalmat szerezhetnének a magyar szülésznők és orvosok a rendszer múködőképességét illetően, és a szülésznők nagyobb felelőssége és önállósága nagymértékben csökkenthetné az orvosokra háruló terhet és munka mennyiségét is. Ezáltal az intézményes szülészeti ellátás minősége is tovább javulhatna.

Egyelőre nem vizsgált területe a magyar szülészetnek az intézeten kívüli szüléshez való szakorvosi hozzáállás, azonban a kismamákkal folytatott beszélgetésekből tudjuk, hogy ha szülész szakorvostól kérnek tanácsot az intézeten kívüli szülésről, az orvosok ezt kevés kivétellel egyértelmúen veszélyesnek tartják, többségében anélkül, hogy ismernék a pontos jogi és szakmai hátterét, feltételeit és múködését, illetve külföldi és hazai eredményeit. Szükség lenne a szakma és a társadalom széles körü és megfelelő tájékoztatására, így teremtődne lehetőség arra, hogy a feltételeknek megfelelő családok megfontolt, felelős döntést hozhassanak a szülés helyszínét illetően. Jelen beszámolónkkal szeretnénk felhívni a szakmabeliek figyelmét a magyar bábapraxisok nemzetközi átlaghoz hasonló jó eredményeire.
A szakma egyelőre nem megfelelő tájékozottsága lehet az egyik oka a kórházi beszállítások során gyakran tapasztalt ellenérzésnek is. A kórházi beszállítások hátterében az intézeten kívül szülészeti ellátás, a szülőanyák és gyermekeik biztonságának megtartása áll. A szakma kiemelten fontos feladatává kellene válnia ezeknek a nehéz helyzeteknek az optimális kezelése. Ideális megoldás lehetne, hogy azokban az esetekben, amikor a szülésznők egy intézeten kívül megkezdett szülésnél a beszállítás mellett döntenek, egy közös protokoll szerint járnának el. E szerint a bábák felhívnák a háttérintézményt, elmondanák, kit visznek, mikor és milyen probléma miatt, majd a beérkezéskor a kórházi orvos vagy szülésznő a beszállító szülésznővel együtt megírná a dokumentáció intézeten kívüli időszakra vonatkozó részét. Ez után a bába továbbra is együtt maradna a kismamával. Az itt vázolt protokoll részleteit az intézeten kívüli szülészeti ellátást szabályozó, 35/2011-es kormányrendelet még nem rögzítette, de a szakma részéről a minisztérium felé már többször érkezett javaslat. Az intézeten kívüli ellátók nagymértékben hozzájárulhatnának a zökkenőmentes beszállításokhoz, amennyiben a családokat az előzetes találkozások alkalmával az esetleges kórházi beszállításra megfelelő információkkal és érzelmi szinten is felkészítenék. Így ilyen körülmények között nagyobb eséllyel úgy tekintenének a beavatkozásokra (például oxytocinos fájáserősítés, gátmetszés, császármetszés), mint szükséges és elfogadható segítségre. Kevésbé éreznék minden helyzetben felesleges, nemkívánatos és káros beavatkozásnak, amely a beszállító szülésznőnek és a fogadó kórházi személyzetnek is a konfliktushelyzetek megelőzését jelenthetné. Ezzel elősegíthetné a szakma a szülők biztonságérzetének fenntartását, a bizalom megmaradását, amely kihatással lehet a következő szülésekre, ezáltal a demográfiai mutatók alakulására, társadalmunk jövőjére.

Anyagi támogatás: A közlemény megírása, illetve a kapcsolódó kutatómunka anyagi támogatásban nem részesült.

Szerzői munkamegosztás: A cikk megírásához L. K. I. a szülésznőképzés múltjának és jelenének tárgyalásával járult hozzá. A cikk végleges változatát mindkét szerző elolvasta és jóváhagyta.

Érdekeltségek: A szerzőknek nincsenek érdekeltségeik.

\section{Köszönetnyilvánítás}

Ezúton szeretnénk köszönetet mondani Prof. Dr. Bártfai Györgynek hasznos észrevételeiért és bátorításáért, illetve Gábor-Kneip Ritának a lektorálásért. 


\section{Irodalom}

[1] Deáky, Z.: The midwife in the Hungarian society. [A bába a ma gyarországi népi társadalomban.] Centrál Európa Közhasznú Alapítvány, Budapest, 1996. [Hungarian]

[2] Szállási, A.: History of the Hungarian obstetrics practices from the beginnings until the end of World War I. [A magyar szülészet története a kezdetektől az I. világháború végéig.] http://www. orvostortenet.hu/tankonyvek/tk-05/pdf_Szallasi/szuleszet_ tortenete.pdf [Hungarian]

[3] Forrai, M.: Main stages of Hungarian midwifery education. [A magyarországi bábaképzés főbb állomásai.] http://vmek. oszk.hu/01800/01887/html/ezerszl3.htm [Hungarian]

[4] Steidele, J.: Hungarian midwifery. [Magyar bábamesterség.] Szeli Károly kiadása, Bécs, 1777. [Hungarian]

[5] Stoeckel, W.: Textbook of obstetrics. [A szülészet tankönyve.] A Magyar Orvosi Könyvkiadó Társulat Kiadása, Budapest, 1930. [Hungarian]

[6] Buda, J.: History of motherhood and midwifery. [Az anyaság és bábaság története.] Pécsi Orvostudományi Egyetem, Egészségügyi Főiskolai Kar, Pécs, 1995. [Hungarian]

[7] Ministry of Welfare: Central programme of midwifery training 1994. [Népjóléti Minisztérium: A szülésznő szakképesítés központi programja 1994.] http://www.odrportal.hu/web/guest/ record/-/record/MOKKAZ0003769137 [Hungarian]

[8] Wiegers, T. A., van der Zee, J., Keirse, M. J.: Maternity care in the Netherlands: the changing home birth rate. Birth, 1998, 25(3), 190-197.

[9] Wiegers, T. A., Keirse, M. J., van der Zee, J., et al.: Outcome of planned home and planned hospital births in low risk pregnan- cies: prospective study in midwifery practices in The Nether lands. BMJ, 1996, 313(7068), 1309-1313.

[10] Johnson, K. C., Daviss, B. A.: Outcomes of planned home births with certified professional midwives: Large prospective study in North America. BMJ, 2005, 330(7505), 1416-1422.

[11] De Jonge, A., van der Goes, B. Y., Ravelli, A. C., et al.: Perinatal mortality and morbidity in a nationwide cohort of 529,688 lowrisk planned home and hospital births. BJOG, 2009, 116(9), 1177-1184.

[12] Birthplace in England Collaborative Group, Brocklehurst, P., Hardy, P., Hollowell, J., et al.: Perinatal and maternal outcomes by planned place of birth for healthy women with low risk pregnancies: the Birthplace in England national prospective cohort study. BMJ, 2011, 343, d7400.

[13] Cheyney, M., Bovbjerg, M., Everson, C., et al.: Outcomes of care for 16,924 planned home births in the United States: The midwives alliance of North America Statistics Project, 2004 to 2009. J. Midwifery Womens Health, 2014, 59(1), 17-27.

[14] World Health Organization: Appropriate technology for birth. Lancet, 1985, 2(8452), 436-437.

[15] Cheyney, M., Everson, C., Burcher, P.: Homebirth transfers in the United States: narratives of risk, fear, and mutual accommodation. Qual. Health Res., 2014, 24(4), 443-456.

(Vincze Felícia, Hódmezôpásárhely, Bercsényi u. 37., 6800 e-mail: felicia@ateszulesed.hu)

\section{Eladó praxis}

Budapesten a XX. kerületben házi gyermekorvosi körzet praxisjoga eladó!

Lakosság száma 784 fő, a kártyaszám $670 \mathrm{db}$. A praxis megvásárlásához az OEP-hez vissza nem térítendő támogatás iránt pályázat nyújtható be.

A körzet a lakosság száma tekintetében megfelel a pályázati feltételeknek.

Az ár alkuképes.

Érdeklődni: Dr. Mozi Diana, Tel: 30/ 999-59-72 